\title{
THE ROCOCO PASTORAL: VERSAILLES'S EROTICISM IN THE POETRY OF MELÉNDEZ VALDÉS
}

Javier Herrero

An immediately apparent characteristic of Meléndez Valdés's poetry is its very strong erotic tone - especially surprising because there is nothing like it in previous Spanish art. As it is well known, not only did the Renaissance and Baroque artists in Spain avoid the most blatant manifestations of classical imitation, of mythological references and motives, but when they used them, they did so carefully playing down the sexual implications and emphasizing their moral or religious character. It is true that some of the Baroque poets, especially Quevedo, wrote very gross poetry, influenced above all by Martial and the great Renaissance humanist such as Poliziano, but this grossness is very far from implying the elegant erotic sensibility that we find in Meléndez Valdés. On the contrary, its brutal analysis of organic activity tends to awaken in the reader a stoic abhorrence of bodily decay as opposed to the spiritual, eternal beauty of the soul's true Eros.

Let us now for a moment direct our attention to two poems of Meléndez Valdés. In the first one, the poet describes the happy lot of a dove which plays on the lap, bosom and throat of Filis (in its first version her name was Cloris, equally bucolic); the poet asks the bird to act as his intermediary between the beloved and himself. Since the poet-lover identifies himself with the dove, it is obvious that the apparently innocent love-making of the girl and the beautiful bird is charged with very strong sensual suggestions. With a typical pastoral conceit, he rejects possible heroic motives and turns to an erotic one:

Otros canten de Marte
Las lides y zozobras
O del alegre Baco
Los festines y copas. .
Pero yo, solo canto
Con citara sonora
De mi querida Filis
La nevada paloma:
Su paloma que bebe
Mil gracias de su boca,
Y en el hombro le arrulla,
Y en su falda reposa.

The comparison between the color of the dove and the white and pink complexion of her bosom brings the lover to some rather daring considerations: 
Teniendo su paloma

Mi Fili sobre el halda

Miré a ver si sus pechos

En el candor la igualan;

$Y$ como estan las rosas

Con su nieve mezcladas

El lampo de las plumas

Al del seno aventaja.

Empero yo, con todo

Cuantas palomas vagan

Por los vientos sutiles,

Por sus pomas dejara. ${ }^{1}$

These verses speak by themselves, and not much subtlety is necessary to perceive the sensual possibilities implied by the identification of the poet with a dove, which is pecking freely over the woman's body. But this sensuality is carried further in the poem Galatea, o la ilusión del canto, where the intermediary between the lover and the beloved is the music itself. Galatea sings a love-song and the poet wishes that the words of love were truly directed to himself. Deluded by his wishful thinking he dares to enter his beloved's bedroom when she is absent. It is her garments which now remind him of her body. We see him touching and kissing these garments in a truly erotic frenzy.

iQué ardor hierve en mis venas!

iQué embriaguez! qué delicia!

i $Y$ en qué fragante aroma

Se inunda el alma mia!

Este es de amor un templo:

Doquier torno la vista,

Mil gratas muestras hallo

Del númen que lo habita.

Del cuello alli las perlas,

$Y$ allá el corsé se mira,

$Y$ en él de su albo seno

La huella peregrina.

i Besadla, amantes labios! . . .

i Besadla! mas tendida

La gasa que lo cubre,

Mis ojos alli fija.

¡Oh gasa! . . iqué de veces! . . .

El piano. .. ven, querida;

Ven, llega, corre, vuela,

Y mi impaciencia alivia. ${ }^{2}$ 
This impatience is, of course, eternal, and all men at all ages have felt it. But how freely was it "aliviada" in the aristocratic circles of 18 th century Spain is something that only the most recent research has shown. It is now fairly well established that the Calderonian spirit of the 17 th century had been replaced, with the arrival of the Bourbon dinasty, and especially with the new Queen Isabel de Farnesio and her Italian ladies-in-waiting, by a new freedom of which the fashion of the "cortejo" was the more scandalous manifestation.

We should, of course, have been warned of this state of affairs by Byron's enthusiastic endorsement of Italian and Spanish customs in Beppo, where he sings the Latin ladies, wild behaviour and their husbands' wise acceptance of cuckoldry, as an obvious proof of the immense superiority of Latin "joie de vivre" over Anglo-saxon prudery.

\section{XXXVI}

Besides, within the Alps, to every woman, (Although, God knows, it is a grievous sin) 'Tis, I may say, permited to have two men: I can't tell who first brought the custom in, But 'Cavalier Serventes' are quite common, And no one notices nor cares a pin; And we may call this (not to say the worst) $A$ second marriage which corrupts the first.

\section{XXXVII}

The word was formerly a 'Cicisbeo', But that is now grown vulgar and indecent; The Spaniards call the person a 'Cortejo' For the same mode subsists in Spain, though recent; In short, it reaches from the Po to Teio And may perhaps at last be o'er the sea sent: But Heaven preserve Old England from such courses! Or what becomes of damage and divorces?

We were made aware of the surprising freedom involved in the "cortejo" fashion with the publication recently of Correa Calderon's two volumes of Costumbristas Españoles. The "cortejo," usually a fashionable, elegant young man about town, would visit his lady at a discreet hour, that is to say around noon, and attended her toilette, discussing her hair style with her coiffeur or her garments with her maids, suggesting colours, commenting on innovations and contemporary, usually foreign, fashions. After having paid this compliment, he would either accompany her in her social calls, rides or shopping, or go by himself to some club, to return later in the evening to serve her lady in her social life: opera, soirees, court attendance, etc. If he had lunch with her at her residence (and in such occasion, good manners imposed the husband's absence), the butler, after coffee and 
liquors were served, would draw the curtains to let the couple enjoy a siesta - of course, with great propriety, the siesta took place on the sofas of the room where the coffee had been served. ${ }^{3}$ Finally, the recent, excellent, book of Carmen Martín Gaite, Usos amorosos del dieciocho en España, leaves no doubt whatsoever about the fact that the "cortejo" became a universal custom in the aristocratic circles of the Spanish society of the times. A lady such as the Marchioness of Villahermosa, who was a devoted and faithful wife-her husband, of course, was a "petit maitre" and a "libertin"-was an object of amused ridicule: she was affectionately called the "little nun" ("la monjita") in the elegant circles where her exalted position placed her. ${ }^{4}$

What Meléndez Valdés and other poets of the Salamanca School really did was to give a language to a society which practiced a "libertinage" as unbound as the one reflected in Boswell's London Journal or Laclos's Les liaisons dangereuses, but which still expressed its feeling and emotions with a Baroque poetic vocabulary, whose images and conceits had nothing whatsoever to do with the new mood of elegant sensuality and cynical abandonment. This is not the place to determine the main characteristics of the Rococo poetical landscape, but a brief description of its essential images can be sketched, as an introduction to our exposition of Meléndez Valdés's sources. The Cardinal Duke of Bernis, the Marquis de Pezay, the Chevaliers of Dorat, Boufflers, Bertin, Parny, etc., created a literary style which, to a great extent, has been (unfairly in my opinion) forgotten due to the extraordinary achievements of the great intellectuals who served the ideals of the emergent bourgeoisie: Voltaire, Montesquieu, Rousseau, Diderot, and so many others, are giants who have crushed the elegant dandies who courted the kings' mistresses and the court ladies with charming and artificial poetry. But these poets were the literary equivalents of the Watteau's and the Fragonards, and their world (the last creation of the European aristocratic society just before its explosion with the French Revolution) possesses an enormous cultural -if perhaps not so much literary-interest for the understanding of our modern history. In my opinion the Rococo world is the last metamorphosis of the Pastoral tradition, but the great elements of the Golden Age have been degraded. The underlying Christian-Platonic structure, which gave to Arcadia its moral strength, has wholly disappeared and a rampant sensuality has replaced the spiritual inspiration of Platonic beauty.The "locus amenus" has been drastically transformed: the clear, simple stream is now an elaborate fountain, a marmoreal structure where the sexual symbols are predominant: the water springs from the breasts of a nymph, or from the mouth of a strongly Freudian fish. Under the trees (no longer the traditional oaks), we fing, not the shepherd playing the flute to the beloved Galatea, but a pseudo-shepherdess who, sitting on a swing, receives the non-platonic adoration of strategically placed companion. The mythological embodiments of this view of Nature are the more superficial and pleasant of the classical deities: Venus, Flora, Zephyr, and hundreds of little Cupids all over the place. In fact, the spiritual projection of a class which - in the middle of the France of beggars, seething with dangerous frustrations, which was their contemporary reality - did their best to create a dream world from which all ugliness was ruthlessly excluded and whose elements were carefully selected natural forms organized towards the glorification of the world of the senses. Arcadia had, then, abandoned its aspiration toward a universal myth and become something that, to a certain extent, had 
been there all along: the cultural expression of a social class, the embodiment of 18 th century aristocratic ideals.

Among the sources which more directly relate to Meléndez Valdés, we shall look first at two poems of Bernis. The Duke of Bernis, the older of the dandies we shall briefly review here, is almost too good to be true. An abbé, expelled from the seminary of Saint Sulpice before taking orders and disowned for this reason by his father, he lived a youth of abject poverty which he bore with unfailing grace and courage. Accepted in the higher circles of French society by reason of his nobility, he literally survived by his wits, since to a great extent he could remain at court only because through his affability, humour, graceful manners and handsome looks, he was a very much sought after guest in the elegant dinners of Versailles or Paris. When the Cardinal de Fleury once told him that if he did not reform he would never get an appointment as long as he (Fleury) was alive, Bernis replied with characteristic wit and nonchalance: "I am prepared to wait" - an answer which, although Fleury himself celebrated it and carried it to the court, was no help at all in his career. However, through his friendship with La Pompadour, Bernis became ambassador to Venice, minister, and later ambassador to Rome, and amassed a colossal fortune which he used with elegance, tact, and great humanity and generosity. A man endowed with the appalling contradictions of his class and his world, his sexual mores seem to have been of an almost 20th century dissoluteness. Casanova, who was acquainted with him during Bernis' ambassadorship in Venice, tells us of a rather significant episode: they became friends through sharing a mistress, a nun in a convent in which another mistress of Casanova was staying at the time. Casanova used the same apartment for his meetings with both women; Bernis having met Casanova's second mistress there, proposed that both should share the two women, to which Casanova, not wanting to hurt the feelings of such a distinguished friend and pleasant gentleman, readily agreed $^{5}$.

I have found two poems of Meléndez Valdés which are clearly Spanish version's of French originals by Bernis. The first is one Bernis wrote to Madame de Pompadour, and its subject cannot be said to be of momentous interest: the dimples that the king's mistress had in her two cheeks. I give here side by side Bernis's and Meléndez Valdés's version:

\section{LES PETITS TROUS}

Conie.

\section{Ainsi qu'Hébé, la jeune Pompadour}

$\left.\begin{array}{l}\text { A deux jolis trous sur sa joue; } \\ \text { Deux trous charmants où le plaisir se joue, }\end{array}\right] 1$

Qui furent faits par la main de l'Amour.

L'enfant ailé, sous un rideau de gaze,

$L a$ vit dormir et la prit pour Psyché.

Qu'elle étoit belle! A l'instant il s'embrase:

Sur ses appas il demeure attaché.

Plus il la voit, plus son délire augmente;

Et, pénétré d'une si douce erreur,

\section{LOS HOYITOS}

iSabes, di, quién te hiciera, Idolatrada mia, Los graciosos hoyuelos De tus frescas mejillas? ¿Esos hoyos que loco Me vuelven; que convidan Al deseo y al labio, Cual copa de delicias?

Amor, Amor los hizo, Cuando, al verte más linda 2 Que las Gracias, por ellas Besarte quiso un dia. ] 3 
Il veut mourir sur sa bouche charmante; ]3 Heureux encor de mourir son vainqueur!

Enchanté des roses nouvelles,

D'un teint, dont l'éclat éblouit,

Il les touche du doigt, elles en sont plus belles; Chaque fleur sous sa main s'ouvre et s'épanouit. Pompadour se réveille, et l'Amour en soupire; Il perd tout son bonheur en perdant son délire: $L$ 'empreinte de son doigt forma ce joli trou,

Séjour aimable du sourire, 15

Dont le plus sage seroit fou. 16
Mas tú, que fueras siempre, Aun de inocente niña, Del rapaz á los juegos Insensible y esquiva,

La cabeza tornabas

$Y$ sus besos huias;

$4 Y$ él, doblando con esto

Más y más la porfía, Apretó con las manos, En su inquietud festiva, La tez llena, süave; $Y$ asi quedára hundida.

De entónces, como á centro
De la amable sonrisa,

En ellos mil vivaces

Cupidillos se anidan. iAh! isi yo en uno de ellos
Transformado! ... su fina

Pürpura no, no ajára

Con mis sueltas alitas.

Pero tú, aleve, ries, $Y$ con la risa misma Más donosos los haces, $Y$ mi sed más irritas. ${ }^{6}$

Although the poem is not a translation, but a rather free version, the dependence upon the French model is clear: in both cases it is the boy Cupid himself who, in love with the beauty of the lady, kisses her and, to keep her face to his lips, presses his fingers against her cheeks, leaving these two little dimples which will grace her smile. In the case of Bernis, of course, the poem has a greater reverence, since its muse was the most influential woman in France and could (and later would) make the author's career; the woman is sleeping (only so could she be kissed by any other than Louis XV), and the poet does not end by presenting himself as seduced by her smile, but asserts that even "le plus sage" would be mad with love over the "joli trou." Meléndez Valdés does not need to fear dire consequences for excessive confidence and paints the girl awake and "esquiva" to "Amor." He is forcing her with his fingers to keep her face still and he does not hide the fact that he would love to follow Cupid's example.

The other two poems whose dependence we want to establish provide a much more complex relationship. Both are poems To the Spring, a favorite 18th century poetic motif, as is well known. Since both are rather long, I shall give here only the fragments that show a clear dependence of Meléndez Valdés on Bernis's poem, not only because of the series of images in which the Spaniard follows the French model, but also because of the order in which they are organized in both poems: snows, forests, birds, herds, and wild animals. Both series of images share, in the same order and in the same way, in the life bestowing breath of the goddess of Spring. What is interesting, however, is to see how 
the culminating episode of both poems, the description of human love, is completely different: in Bernis we find a mythological story of great sensuality, in which Zéphyr, the Spring wind-god, looks for a virgin (exploring sleeping girl), sweetly possesses her in her sleep, and the girl finds out in her dream that it is not in Heaven that happiness exists, but in that fire, more pleasant than that of the stars, which burns in terrestrial Nature. She ends her dream by being possessed by her lover amidst an enchanted Nature of love-breathing forests. Meléndez Valdés has suppressed the rather irreverent description of the girl's rejection of Heaven, and has concluded his poem with an elaboration of the forest's idyl.

Dans les antres de la Scythie Vertumne, vainqueur des hivers, Vient de remettre dans les fers Les fougueux enfants d'Orithye. En vain leurs affreux sifflements Nous déclarent encor la guerre;

En vain, dans leurs soulèvements,

Ils ébranlent les fondements

De la prison qui les resserre:

Le printemps a sauvé la terre

De leurs cruels emportements. . .

$L$ 'hiver s'enfuit au fond du nord; . . .

Le fils d'Éole et de l'Aurore, Zéphire, enfin est de retour; Ses transports ont réveillé Flore; Et les fleurs qui n'osoient éclore S'ouvrent aux feux de leur amour:...

Le soleil, que nous revoyons, Orne sa tête des rayons Qui rendent la terre féconde. Déjà des lacs les plus profonds Ses feux ont fondu la surface; On voit tomber du haut des monts Des monceaux de neige et de glace Qui fertilisent les vallons;

Les rochers découvrent leur cime, Dodone lève un front sublime
$Y$ al mundo, que en grillos

De hielos y nieves

Tuvo el crudo invierno,

La esperanza vuelve;

La dulce esperanza

De que Mayo alegre

Lo colme de rosas,

$Y$ el Julio de mieses.

El blando Favonio, Que llegar la siente, Con grato susurro Las alas extiende; $Y$ en torno vagando,

Su manto esplendente

Por el éter puro

Fugaz desenvuelve.

Del cándido seno

Con su soplo llueven

Sin cuento las flores, Que el suelo enriquecen; . . . .

Las rosadas puertas Del fúlgido oriente Al sol, que entre albores Galan amanece,

Su augusto semblante, Su rayo clemente, Del yerto Fuenfria Los hielos disuelven;

Que súbito vueltos

En raudos torrentes, 
Que respectent les aquilons; Et, de l'hiver tendre victime, Cérès, du sein de nos sillons, Sourit au dieu qui la ranime. .

Les arbres se courbent en voûte; $L$ 'onde, plus pure dans sa route, Réfléchit l'image des cieux. Content, il se lève, il s'écrie; Et tandis que la bergerie Se réveille et s'ouvre à sa voix, Le troupeau, marchant sous ses lois, Bondit déjà dans la prairie.

Arbres dépouillés si longtemps, Couronnez vos têtes naissantes, Et de vos fleurs éblouissantes Parez le trône du printemps. Ellevez vos pampres superbes Sur le faite de ces ormeaux, Vignes, étendez vos rameaux; Jasmins, sortez du sein des herbes;. .

Voyons ces taureaux mugissants Poursuivre Io dans les prairies; Voyons ces troupeaux bondissants Donner, par leurs jeux innocents, Aux bergères des rêveries, Aux bergers des désirs pressants,

Ocyroé dans les campagnes Enflamme par ses fiers regards Le coursier, amant des hasards; Elle l'enlève à ses compagnes; Et s'élançant, les crins épars, Tous deux, au sommet des montagnes, Offrent leur hymen au dieu Mars. Plus loin, dans ces forêts sauvages, Les lions rugissent d'amour, Tandis que les ramiers volages Viennent soupirer alentour;... .
De su excelsa cumbre Ruidosos descienden; Del húmedo valle

La pompa mantienen, $Y$ al cabo en sus flores Sesgando se pierden...

Las selvas que el cierzo Desnudó en Noviembre, De yemas pobladas Sus ramas ya ofrecen; Do mal contenidas Las hojas nacientes, Sus rudos capullos A abrirse compelen;

$Y$ al trépido rayo Con que el sol las hiere, Tienden sus cogollos, Y el viento los mece. . No ya en sus guaridas El hielo entorpece, Ni undosa la lluvia Los brutos detiene; Que vagos y libres Doquier aparecen, $Y$ en bosques $y$ valles Su dominio ejercen...

El leon amante Rugiendo estremece Los anchos desiertos Del Arica ardiente. El oso, aunque rudo, Su cetro obedece, Que dóciles torna Los tigres crueles. Su veneno el potro Con las auras bebe; Las ondosas crines Sacude demente; Bate el duro suelo, Fogoso se mueve, $Y$ hace que los montes Sus relinchos llenen. Del pasto olvidado, De amor se enfurece 
Un enfant aimable et pervers Enlève aux Grâces leur ceinture; Pudeur, jeunesse, amour, nature, Tous vos secrets sont découverts. Déjà d'une beauté naissante Le sylphe interroge le coeur, Sa main timide et caressante Cherche les traces d'un vainqueur;... . Un gazon frais, une fontaine, Un arbre qui cache le jour, Tel est l'asile que l'Amour Préfère à la céleste plaine. A peine a-t-elle désiré, Que le char brillant qui la mène S'arrête sous l'ombre incertaine D'un bois par un fleuve entouré. A l'instant les buissons fleurissent, La vigne embrasse les ormeaux, Les palmiers amoureux s'unissent, L'air est peuplé de mille oiseaux. C'en est fait, la jeune sylphide S'enivre du bonheur des dieux. Mais le soleil brille à ses yeux; Le songe fuit d'un vol rapide, Et le sylphe remonte aux cieux.
En pos de la novilla

El toro valiente;

$Y$ al rival que el triunfo

Disputarle quiere, Con botes tremendos Celoso acomete;

Ahuyéntalo, y solo Los premios obtiene, Que en roncos mugidos Feroz engrandece. . .

El bosque enramado, Do el ciego mantiene Para sus misterios Callados retretes, Que ocultos y umbrosos Anhelan y temen El pudor cobarde $Y$ el deseo ardiente, De amantes felices Ya rinde desdenes, Ya audacias alienta, Ya triunfos entiende.

iDulcisimos triunfos! Que de un velo envuelve, $Y$ el recato esconde Del mismo que vence. iOh repuestos valles! iLadera pendiente! iAltisima sierra, Que las nubes hiendes! iOh icómo al miraros Ora florecientes, Los ojos se gozan $Y$ el pecho enloquece! Las auras se inundan De süaves pebetes; Con toda su gloria Ya el sol resplandece;

$Y$ tierras y cielos, Del año naciente La pompa celebran, $Y$ en júbilo hierven, ...?

Bernis, Durat, and Boufflers were a source of inspiration for a group of young courtiers about Louis XVI, most of them "écuyers" of Marie-Antoinette, in whom the 
last flowering of erotic poetry of the Ancient Regime finds its best and most representative expression. A young officer, the Marquis de Parny, had bought a property in Feuillancour near Versailles and lived there with his brother Évariste-Désiré, Bertin, Bonnard, Boufflers, and other young men equally devoted to the service of Cupid and of the muses. The Marquis de Boufflers, older than most of these courtiers, had been one of the great models of charm and libertinage of the century: a séminariste, as was Bernis, he was expelled for writing a long pornographic poem, and had found his true vocation in the army where, as Bernis had in diplomacy, he made a brilliant career. At the time of his residence in Feuillancour, ha had somehow mended his ways and settled down to domestic bliss through his marriage to the charming and devout Countess of Sabran; but his newly found moderation did not prevent him from enjoying the company of the not-so-wise young officers in whon he found the same delight in the "belles lettres" that he himself had always had. One of the young poets, Bertín, has left a description of the activities of the group:

Nous sommes depuis trois semaines à Feuillancour, et tels à peu près que tu nous as laissés, si ce n'est que ton frère est devenu encore plus gourmand, et moi plus paresseux, depuis que nous avons été inoculés. Le soleil est à peu près au tiers de sa course lorsqu'on se lève: et pour remplir alors ce que nous nommons bravement la matinée, on s'occupe de vers, de prose, de musique et d'autres semblables bagatelles. Le soleil baisse, nos dames montent dans des calèches découvertes que nous conduisons nous-mêmes avec assez d'adresse; nous courons jouir, sur cette longue et superbe terrasse de Saint-Germain, d'un des plus beaux aspects qui soit au monde, et nous nous égarons dans les mille et une routes de la forêt. La soirée est terminée par un souper fort gai et par des chants qui se prolongent fort avant dans la nuit. ${ }^{8}$

Two poems, among the many produced by this elegant group, especially interest us here, because they are perfect examples of this highly polished sensuality which we find in Meléndez Valdés and the School of Salamanca. Both poems were referred to in the beginning of this paper. I should now like to look a little more closely at these poems. The first one, a poem of Bonnard's entitled "En donnant un Serin" I include here only to suggest it as a possible source for "La Paloma de Filis," of which we gave a description earlier in our paper.

\section{EN DONNANT UN SERIN}

Aimé, chéri, caressé de Sylvie, Obtenant tout et ne désirant rien, Heureux oiseau! que je te porte envie! Et que mon sort est différent du tien! Ah! s'il étoit justice dans la vie, Tout ton bonheur devroit être le mien. 
Faut-il te voir auprès de ma bergère,

Sur ses genoux, sur son cou, sur ses bras,

Les parcourant de ton aile légère,

Impunément becqueter tant d'appas?

S'il ne falloit que t'imiter pour plaire,

Dieux! quels plaisirs ne goûterois-je pas!

Va! sois heureux autant que tu peux l'être.

Que ma Sylvie écoute tes chansons!

Chante l'amour et les biens qu'il fait nattre;

Peins-lui mes feux dans tes flexibles sons;

Fais-la rêver, et mon bonheur peut-être

Sera le fruit de tes douces leçons. ${ }^{9}$

Much more interesting is, in my opinion, the relationship between the ode "El gabinete," which is, in Meléndez Valdés, part of the long poem Galatea o la ilusion del canto (which we partially quoted at the beginning of this paper) and Parny's "Le cabinet de toilette." Here are the two poems side by side:

\section{LE CABINET DE TOILETTE}

$\left.\begin{array}{l}\text { Voici le cabinet charmant } \\ \text { Où les Grâces font leur toilette. }\end{array}\right] 2$

Dans cette amoureuse retraite

J'éprouve un doux saisissement. $] 1$

Tout m'y rappelle ma maittresse,

Tout m'y parle de ses attraits; ] 2

Je crois l'entendre; et mon ivresse

La revoit dans tous les objets. $] 1$

$\mathrm{Ce}$ bouquet, dont l'eclat s'efface,

Toucha l'albâtre de son sein;

Il se dérangea sous ma main,

Et mes lèvres prirent sa place.

Ce chapeau, ces rubans, ces fleurs,

Qui formoient hier sa parure,

De sa flottante chevelure

Conservent les douces odeurs.

Voici l'inutile baleine
Où ses charmes sont en prison. 5

J'apperçois le soulier mignon

Que son pied remplira sans peine.

Ce lin, ce dernier vêtement...

Il a couvert tout ce que j'aime:

Ma bouche s'y colle ardemment, 6

Et croit baiser dans ce moment

Les attraits qu'il baisa lui-même.

\section{EL GABINETE}

¡Qué ardor hierve en mis venas! ¡Qué embriaguez! ¡qué delicia!

iY en qué fragante aroma

Se inunda el alma mia!

Este es de amor un templo:

Doquier torno la vista,

Mil gratas muestras hallo

Del númen que lo habita.

Aqui el luciente espejo

$Y$ el tocador, do unidas

Con el placer las Gracias,

Se esmeran en servirla,

$Y$ do esmaltada de oro

La porcelana rica,

Del lujo preparados,

Perfumes mil le brinda;

Coronando su adorno

Dos fieles tortolitas,

Que entreabiertos los picos

Se besan y acarician.

Alli plumas y flores,

El prendido y la cinta

Que del cabello y frente

Vistosa en torno gira;

$Y$ el velo que los rayos 
Cet asile mystérieux

De Vénus sans doute est l'empire.

Le jour n'y blesse point mes yeux;

Plus tendrement mon coeur soupire;

L'air et les parfums qu'on respire

De l'amour allument les feux.

Parois, ô maitresse adorée!

J'entends sonner l'heure sacrée

Qui nous ramène les plaisirs;

Du tems viens connoître l'usage,

Et redoubler tous les désirs

Qu'a fait naître ta seule image.
Con que sus ojos brillan,

Doblándoles la gracia,

Emboza y debilita.

Del cuello alli las perlas;

$Y$ alla el corsé se mira,

$Y$ en él de su albo seno

La huella peregrina.

¿Besadla, amantes labios!

¡Besadla! . . mas tendida

La gasa que lo cubre,

Mis ojos alli fija.

¡Oh gasa! . . ;qué de veces! ... 6

El piano... vén, querida;

Ven, llega, corre, vuela,

$Y$ mi impaciencia alivia.

¡Oh! cuánto en la tardanza

Padezco! icuál palpita

Mi seno! „en qué zozobras

Mi espiritu vacila!

En todo, en todo te halla

Mi ardor. . tu voz divina

Oigo feliz. . . mi boca

Tu süave aliento aspira.

$\begin{array}{ll}Y \text { el aura que te halaga } & 7\end{array}$

Con ala fugitiva,

De tus encantos llena,

Me abrasa y regocija.

Mas ¿si serán sus pasos? ...

Si, si; la melodia

Ya de su labio oyendo,

Todo mi ser se agita.

Sigue en tus cantos, sigue;

Vuelve á sonar de Armida

Los menazantes gritos,

Las mágicas caricias.

Trine armonioso el piano,

$Y$ á mi rogar benigna,

Cual ella por su amante,

Tú asi por mí delira.

Clama, amenaza, gime,

$Y$ en quiebros $y$ ánsias rica,

Haz que ardan nuestros pechos

En sus pasiones mismas;

Que tú cual ella anheles.

Ciega de amor y de ira; 


\author{
Y yo rendido y dócil \\ Tu altiva planta siga. \\ Y tú sosténme, ioh Vénus! \\ Sosténme; que la vida \\ Entre éxtasis tan gratos, \\ Débil sin tí, peligra.
}

It is quite obvious that Meléndez Valdés has developed in a very sensitive and rather elegant way the main events of Parny's poem - in fact, he has left nothing out and has added only two elements: the porcelain with the two doves kissing and the piano which waits for her music, both characteristic images of Meléndez's poetry. Otherwise, even the order is almost identical: 1) The "ardor hierve en mis venas" is the "ivresse" and the "doux saisissement," when he enters the beloved's bedroom. 2) Meléndez Valdés makes a Temple of the Graces, and he sees her possessions as samples of the goddess who inhabits it; for Parny, it is the place where "les Grâces font leur toilette," although the goddess is - less exalted than Meléndez - only his "maîtresse;" 3) In the image of the kissing doves, as we said before, Meléndez is simply himself: the doves making love is a constant image of erotic bliss all through his poetry, and he cannot resist the temptation to make the porcelain of two kissing doves preside over a room which he has made a Temple of the Graces. It replaces the bouquet of Parny who, more daring than Meléndez, had displaced it with his hand. 4) The "plumas, flores, cintas" of her hat is an almost direct translation of the "Ce chapeau, ces rubans, ces fleurs," although Meléndez has added the feathers and a veil. 5) The "corsé" with the "huella" of the "albo seno" is, again, an improvement on "l'inutile baleine - Où ses charmes sont en prison." 6) When the lover sees the last garment, the Frenchman allows himself, not surprisingly, a greater freedom than the Spaniard: "Ce lin, ce dernier vêtement...-Il a couvert tout ce que j'aime:- Ma bouche s'y colle ardemment, - Et croit baiser dans ce moment - Les attraits qu'il baisa lui-même.;" Meléndez has kissed the "corsé", but looking to this last silky garment, surprisingly, in ecstatic impatience he asks for the piano and for the beloved to come to play on it - I leave to a competent psychologist the possible interpretation of this metaphor. 7-8) The last part is elaborated much more in Meléndez's poem, but in both we find the images of an aura which lights up the fires of love and which to both poets suggests the presence of Venus and expectation of the arrival of their beloved. ${ }^{10}$

More evidence could be produced with regard to the general French influence in Meléndez Valdés and, indeed, in the whole Salamanca School of which he is the most distinghished representative. Georges Demerson, in his excellent study Don Juan Meléndez Valdés et son temps (1754-1817) has collected an impressive amount of documents which show, not only the presence of the great French authors in the Spanish writer, but the incredible extent of his devotion to French culture. In fact, of the 352 volumes of his library which Demerson has carefully reconstructed (and which are, obviously, only a modest part of the total library) 11 are Greek, 69 Latin, 12 English, 13 Italian, 3 Portuguese, 45 Spanish, and 199 French! ${ }^{11}$ Not only did he have four French books for each Spanish one, but the amount of French books were almost four 
times the figure of all the others put together. Meléndez Valdés is, probably, one of the most impressive examples of what the French Enlightment meant for Europe. A professor, a lawyer, a politician, a poet, and an elegant man who frequented the aristocratic "salons" to which his professional and artistic achievement gave access, in many ways he was an instrument for the penetration of the Enlightment into Spain; but an aspect of his influence which has been disregarded and which, in my opinion, is not without significance, is his role as an erotic poet. As such, he gave to an aristocratic society, whose mores were very much contemporary, a new literary language. He threw away the already useless grandiose Baroque expression and replaced it with the delicate, artificial, decadent mythology of the Rococo pastoral: this lovely Trianon where María-Antoinette was still playing when the other children of the Enlightment, the "sans-coulottes", came to replace the Arcadian oak with its proletarian counterpart, the guillotine.

University of Pittsburgh

\section{NOTES}

${ }^{1}$ Poesías de Meléndez Valdés, in Poetas líricos del Siglo XVIII. Biblioteca de Autores Españoles. Tomo LXIII, Volumen II (Madrid, 1952), 111-112. All quotations of Meléndez Valdés' poetry will be from this edition.

${ }^{2}$ Id. 117-118.

${ }^{3}$ Clavijo y Fajardo. "Los cortejos"; "Vida ociosa de muchas de nuestras damas"; "Vida ociosa de algunos caballeros"; "Mas sobre los cortejos"; in Costumbristas españoles. Ed. E. Correa Calderon; Aguilar (Madrid, 1964), Tomo I, 479-499.

${ }^{4}$ Carmen Martin Gaite. Usos amorosos del dieciocho en España (Madrid, 1972), 143-145.

${ }^{5}$ Poésies diverses du cardinal De Bernis avec une Notice bio-bibliographique, Ed. Fernand Drujon (Paris, 1882). For the whole episode of Bernis and Casanova, see Giacomo Casanova, History of my Life (New York, 1967). Vol. 4. Chapter 6-8. Pages 92-130. It is curious to read Bernis's judgement of his own morality: "Tout ce que je puis dire, c'est que dans ma jeunesse j'ai en beaucoup de reproches à me faire comme chrétien, mais aucun comme honnête homme. J'ai fui la mauvaise compagnie, et j'ai toujours eu en horreur le libertinage" (op. cit. XXIII-XXIV). In his epistle "Contre le libertinage" we see that what he understands by "libertin" a aperson who seduces for the cruel vanity of dominating and degrading innocence, as 'Valmont' in Les liaisons dangereuses. The veracity of the episode is documented in Casanova, J.R. Childs (London, 1961), 77-88.

6 “Los hoyitos," Meléndez Valdés, op. cit, 105; Bernis, op. cit. 210-11.

7 "La primavera," Meléndez Valdés, 129-130; Bernis, 23-37.

${ }^{8}$ Poésies et oeuvres diverses du chevalier Antoine Bertin. Avec une Notice bio-bibliographique par Eugene Asse. (Paris, 1879). XX-XXII. The poems of this group of courtiers and officers were usually published in the Almanach des Muses, between 1770-1785 (op. cit. ip. XIII). I have no doubt that Meléndez Valdés read them there.

${ }^{9}$ Poésies diverses du chevalier De Bonnard. Avec une Notice bio-bibliographique par H. Martin Dairvault. (Paris, 1884), 175-176. 
10 See Maléndez Valdés, "El gabinete", 110-118; and Parny, "Le cabinet de toilette," in Le chevalier de Parny et ses poésies érotiques, Leon de Forges de Parny (Paris, 1949) 140-141. Georges Demerson, in his extremely erudite discussion of the French sources of Meléndez Valdés, writes that both Parny and Meléndez Valdés had as direct source Letter LIV, of Book I of Rousseau's La nouvelle Héloïse. A careful reading of both texts has persuaded me that, although there is no doubt that Meléndez Valdés knew the letter, and that there are some reminiscences in his poem, he depended very directly on Parny's poem, as I think that my analysis makes quite clear. For a full discussion see Georges Demerson, Don Juan Meléndez Valdés et son temps (1754-1817) (Paris, 1962) 489-496, especially 493-495; an relevant bibliography will be found there.

11 Georges Demerson; op. cit. 61-78. 